\title{
Assessment of Serum Zinc Status of Children
}

\author{
Hatice Gunes $^{1 *}$, Can Acipayam², Serkan Kirik ${ }^{3}$, Sevcan Ipek ${ }^{1}$ \\ ${ }^{1}$ Department of Pediatrics, Sutcu Imam University, Kahramanmaras, Turkey \\ ${ }^{2}$ Department of Pediatric Hematology, Sutcu Imam University, Kahramanmaras, Turkey \\ ${ }^{3}$ Department of Pediatric Neurology, Sutcu Imam University, Kahramanmaras, Turkey
}

*Corresponding Author: Dr. Hatice Gunes, Department of Pediatrics, Faculty of Medicine, Sutcu Imam University, Kahramanmaras, 46050 Turkey

Received: 08 September 2018; Accepted: 15 October 2018; Published: 21 November 2018

\begin{abstract}
Objective: Zinc is an important trace element in terms of children being able to grow and develop normally and to be protected from diseases and it is also essential for most of the enzymes to be able to function normally. In this study, we aimed to evaluate the serum zinc status of children who admitted to our hospital.
\end{abstract}

Material and Methods: A total of 88 subjects (61 cases, 27 controls) who admitted to our hospital within the past year-aged between 0-48 months and whose serum zinc levels were analyzed included to study. The subjects were divided into two groups according to their diagnosis: patient or case and control group. The patient group consisted of patients who applied to our hospital due to any health problem, whereas the control group consisted of patients who had no health problems. Serum zinc and other electrolytes $(\mathrm{Ca}, \mathrm{Mg}, \mathrm{Na}, \mathrm{K}, \mathrm{P}, \mathrm{Cl})$ levels and diagnosis of patients were recorded to patient files and statistical analyses were performed.

Results: Serum mean levels of $\mathrm{Zn}$ and $\mathrm{Ca}$ in the case group were lower than those of the control group ( $\mathrm{p}=0.011$ and 0.013 respectively). There was no significant difference in the serum levels of other electrolytes between the case and control groups.

Conclusion: We want to emphasize that measurements of serum zinc levels in children's follow-ups should be done.

Keywords: Zinc; Child; Development; Infection 


\section{Introduction}

Zinc is an essential trace element that plays an important role in many biological functions and is essential for children to ensure a healthy lifespan and sustain normal growth and development. It is an important component of most enzymes involved in protein, lipid, and carbohydrate metabolism [1]. It can also be found in the pancreas, liver, retina, bones, skin, kidneys and blood cells, as well as in the muscle [2]. For optimal health, a certain amount is required every day. Zinc is necessary for normal growth and development in children, and it protects children from recurrent infections that are taken in adequate amounts, reducing the frequency of diarrhea and pneumonia [3]. Zinc deficiency is one of the most widespread micronutrient deficiencies [3].

Clinical manifestations include zinc deficiency, growth retardation, hypogonadism, hepatosplenomegaly, parakeratosis, alopecia, delayed wound healing, congenital anomalies, intrauterine growth retardation, increased sensitivity to infections, impaired neurophysiological performance and impaired sense of smell [4]. Studies have shown that serum zinc levels decrease in infectious and inflammatory conditions [5]. In zinc deficiency, it has been shown a loss in T and B cell maturation and changes in the secretions of some cytokines [6]. The aim of this study is to evaluate the serum zinc status of infants who admitted to a tertiary health institution and its relationship with infections and other clinical conditions.

\section{Material and Methods}

This retrospective study was carried out in a university hospital serving as a tertiary health care institution in the southern region of Turkey. Eighty-eight children who were admitted to our hospital within the past year -aged between 0-48 months-and whose serum zinc levels were studied included in this study. The study was approved by the local ethics committee. Patients' age, gender, clinical diagnosis, serum zinc, and electrolyte levels were recorded by scanning patient files. According to the diagnosis, patients were divided into two groups, case, and control. The patient group consisted of patients who applied to our hospital due to any health problem, whereas the control group consisted of patients who had no health problems. These health problems consistent of respiratory infections, hyperbilirubinemia, feeding problems, growth retardation, skin disorders, and other conditions. There were 61 individuals as case group and 27 as the control. Serum levels of $\mathrm{Mg}, \mathrm{Ca} \mathrm{Na}, \mathrm{P}, \mathrm{Cl}$ and $\mathrm{K}$ were measured using a photometric method using an autoanalyzer device, and serum $\mathrm{Zn}$ was measured by atomic absorption spectrophotometry. Serum zinc levels between $50-150 \mu \mathrm{g} / \mathrm{dl}$ were considered normal.

\section{Statistical Analysis}

The collected data were tabulated and analyzed using SPSS version 16 software (SPSS Inc, Chicago, IL, USA). Categorical data are expressed as percentages and numbers, while quantitative data are given as median, interquartile range, and range. Student's t-test and Mann-Whitney U-test were used as tests of significance. The accepted level of significance in this work was stated at 0.05 ( $\mathrm{P}<0.05$ was considered significant). 


\section{Results}

The mean age of study cases was $6.37 \pm 7.75$ months and that of the control group was $4.18 \pm 6.82$ months indicating a statistically insignificant difference $(\mathrm{p}=0.144)$. There was no significant difference between the groups in terms of sex ( $\mathrm{p}=0.364)$. Also, serum mean levels of $\mathrm{Zn}$ and $\mathrm{Ca}$ in the case group were lower than those of control group ( $\mathrm{p}=0.011$ and 0.013 respectively). There was no significant difference in the serum levels of other electrolytes between the case and control groups (Table 1). The distribution of serum $\mathrm{Zn}$ levels in the study group according to the reasons for admission is shown in Table 2.

\begin{tabular}{|l|l|l|l|}
\hline Group & Case $(\mathbf{n = 6 1})$ & Control $(\mathbf{n}=27)$ & P value \\
\hline Age $(\mathrm{months})$ & $6.37 \pm 7.75$ & $4.18 \pm 6.82$ & $\mathrm{P}=0.144$ \\
\hline Male/ Female & $38 / 23$ & $14 / 13$ & $\mathrm{P}=0.36$ \\
\hline $\mathrm{Zn}(\mu \mathrm{g} / \mathrm{dl})$ & $77.34 \pm 21.12$ & $92.65 \pm 33.39$ & $0.011^{*}$ \\
\hline $\mathrm{Na}(\mathrm{mmol} / \mathrm{l})$ & $140.38 \pm 2.2$ & $140.28 \pm 1.16$ & 0.876 \\
\hline $\mathrm{K}(\mathrm{mmol} / \mathrm{l})$ & $5.01 \pm 0.49$ & $5.24 \pm 0.55$ & 0.172 \\
\hline $\mathrm{Ca}(\mathrm{mg} / \mathrm{dl})$ & $9.98 \pm 0.49$ & $10.42 \pm 0.48$ & $0.013^{*}$ \\
\hline $\mathrm{P}(\mathrm{mg} / \mathrm{dl})$ & $5.50 \pm 0.81$ & $5.80 \pm 0.69$ & 0.267 \\
\hline $\mathrm{Mg}(\mathrm{mg} / \mathrm{dl})$ & $2.11 \pm 0.15$ & $2.41 \pm 1.16$ & 0.420 \\
\hline $\mathrm{Cl}(\mathrm{mmol} / \mathrm{l})$ & $106.96 \pm 3.08$ & $107.4 \pm 2.45$ & 0.690 \\
\hline
\end{tabular}

$* \mathrm{P}<0.05$ was considered significant.

Table 1: Comparasion of Groups According to Demographic and Laboratory Data.

\begin{tabular}{|l|l|}
\hline Group (n) & Zn level $(\boldsymbol{\mu g} / \mathbf{d l})$ \\
\hline Respiratory infection (19) & $78.30 \pm 19.54$ \\
\hline Skin disorders (6) & $71.35 \pm 22.06$ \\
\hline Hyperbilirubinemia (8) & $72.55 \pm 19.50$ \\
\hline Feeding problems (5) & $107.3 \pm 26.14$ \\
\hline Growth retardation (5) & $87.40 \pm 15.11$ \\
\hline Constipation (3) & $67.46 \pm 8.63$ \\
\hline Other (15) & $69.70 \pm 17.77$ \\
\hline Control (27) & $92.65 \pm 33.39$ \\
\hline
\end{tabular}

Table 2: Distribution of Zn levels.

\section{Discussion}

Zinc is an essential mineral for the organism. It is a biological trace element that needs to be taken a certain amount each day for optimal health [4]. Zinc levels decrease during infections as a result of the increase in both zinc use and zinc loss. Our results showed that; compared with the healthy control subjects, children who admitted to hospital for 
a health problem i.e. jaundice, respiratory tract infections or other infections, feeding problems, constipation, and growth retardation had significantly lower serum concentration of $\mathrm{Zn}$. These results were consistent with the studies of Cvijanovich et al, Linko et al and Negm et al who detected low levels of $\mathrm{Zn}$ in critically ill children compared with controls [7-9]. Navarro-Alarcon et al., Cabre et al. and Negm et al. found Zn concentration decreased more in patients with chronic illness, there were no chronic patients in our study but we found same results in subjects with acute illness [9-11]. It is estimated that zinc is important also in acute illness conditions.

Zinc decreases the enterohepatic circulation of bilirubin. In a study, it was observed that the serum bilirubin levels decreased when oral zinc salt was given to hyperbilirubinemic rats [12]. However, it has been shown that oral zinc administration does not reduce the incidence of hyperbilirubinemia and the need for phototherapy, in newborns up to one week old [13]. In our study, $13.4 \%$ of the case group were hyperbilirubinemic patients and it is consistent with the literature. Anorexia is the first symptom of zinc deficiency. Glucopruvic stimulation increases nutrient uptake and carbohydrate selection. On the third day of zinc-poor diet in mice, anorexia developed and it was observed that nutrient uptake did not increase after 2-Deoxy-D glucose stimulation. It is predicted that this is caused by the ability to detect blood glucose concentration during zinc deficiency [14]. 16.39\% of the case group consisted of patients with developmental growth retardation and feeding complaints such as loss of appetite.

Skin is rich in zinc, approximately $20 \%$ of whole body zinc is found in the skin. Epidermis layer contains 5-6 times more zinc than dermis [15]. Zinc deficiency causes some skin problems such as acne, dermatitis, eczema, dry skin, alopecia, delayed wound healing and stomatitis [16]. In our study group, $9.8 \%$ of subjects had skin problems as mentioned above which was in accordance with the literature. The group with the lowest zinc level in the case group consisted of those with constipation. As mentioned in the article of JM Hutson et al. some adolescents have potassium or zinc deficiency, presumably related to poor diets in association with colonic irrigation [17].

There was no adolescent age group in our study, but also zinc impairment in younger age groups may be related to constipation, but it is necessary to have a number of cases to be able to estimate that. We found that the serum zinc levels of the studied patients were above the cut-off value determined by the laboratory. We think that this may be due to the close follow-up and supportive treatment policies provided to all babies in our country. The serum calcium levels in the patient group were lower than in the control group and this decrease was statistically significant. However, in both groups, these levels were at normal intervals and had no clinical significance. The number of patients and the small number of subgroups are among the limitations of our study. Further studies can be conducted with larger patient groups performing more detailed examinations.

\section{Conclusion}

In conclusion, we wanted to emphasize that zinc level inspections should be done in order to ensure growth and development in children, especially infants, and to protect them from the disease. 


\section{Contributions}

HG, SI: Collected the patient data and wrote the manuscript; CA: Checked and corrected the manuscript; SK: Did statistical analysis. HG will act as guarantor for the paper.

\section{Conflict of Interest}

No conflict of interest was declared by the authors.

\section{Financial Disclosure}

The authors declared that this study has received no financial support.

\section{References}

1. Salehiomran MR, Mahzari M. Zinc status in febrile seizure: a case-control study. Iran J Child Neurol 7 (4) (2013): 20-23.

2. Rostan EF, DeBuys HV, Madey DL, et al. Evidence supporting zinc as an important antioxidant for skin. Int J of Dermatol 4 (2002): 606-611.

3. Brown KH, Rivera JA, Bhutta Z, et al. Assessment of the risk of zinc deficiency in populations and options for its control. International Zinc Nutrition Consultative Group (IZiNCG) technical document \#1, Food Nutr Bull 25 (2004): 99-203.

4. Belgemen T, Akar N. Vital Functions of Cinkone and Genes Associated with Cinko Metabolism. Ankara University Medical Faculty Journal 57 (2004): 161-166.

5. Lonnerdal B. Dietary factors influencing zinc absorption. The Journal of nutrition 130 (2000): 1378-1383.

6. Kumar S, Singh S. Zinc and selenium in critically ill children. Where do they stand? IPP 2 (2014): 297306.

7. Cvijanovich NZ, King JC, Flori HR, et al. Zinc homeostasis in pediatric critical illness. Pediatr Crit Care Med 10 (2009): 29-34.

8. Linko R, Karlsson S, Pettila V, et al. Serum zinc in critically ill adult patients with acute respiratory failure. Acta Anaesthesiol Scand 55 ( 2011): 615-621.

9. Negm FF, Soliman DR, Ahmed ES, et al. Assessment of serum zinc, selenium, and prolactin concentrations in critically ill children. Pediatric Health Med Ther 7 (2016): 17-23.

10. Navarro-Alarcon M, Reyes-Pérez A, Lopez-Garcia H, et al. Longitudinal study of serum zinc and copper levels in hemodialysis patients and their relation to biochemical markers. Biol Trace Elem Res 113 (2006): 209-222.

11. Cabre M, Camps J, Paternain JL, et al. Time-course of changes in hepatic lipid peroxidation and glutathione metabolism in rats with carbon tetrachloride- induced cirrhosis. Clin Exp Pharmacol Physiol 27 (2000): 694-699.

12. Vitek L, Muchova L, Zelenka J, et al. The effect of zinc salts on serum bilirubin levels in 
hyperbilirubinemic rats. J Pediatr Gastroenterol Nutr 40 (2005): 135-140.

13. Mishra S, Cheema A, Agarwal R, et al. Oral zinc for the prevention of hyperbilirubinemia in neonates. Cochrane Database Syst Rev 7 (2015): CD008432.

14. Cole AC. Zinc deficient rats are insensitive to glucoprivation caused by 2-deoxy-D-glucose. Nutr Neurosci 5 (2002): 59-64.

15. Rostan EF, DeBuys HV, Madey DL, et al. Evidence supporting zinc as an important antioxidant for skin. Int J of Dermatol 4 (2002): 606-611.

16. Bin BH, Hojyo S, Seo J, et al. The Role of the Slc39a Family of Zinc Transporters in Zinc Homeostasis in Skin. Nutrients 16 (2018): 10.

17. Hutson JM, McNamara J, Gibb S, et al. Slow transit constipation in children. J Paediatr Child Health 37 (2001): 426-30.

Citation: Hatice Gunes, Can Acipayam, Serkan Kirik, Sevcan Ipek. Assessment of Serum Zinc Status of Children. Journal of Pediatrics, Perinatology and Child Health 2 (2018): 10-15.

(C) 1 This article is an open access article distributed under the terms and conditions of the 